\title{
Investigation of potential anti-urolithiatic activity from different types of Musa pseudo-stem extracts in inhibition of calcium oxalate crystallization
}

\author{
Mazni Abu Zarin ${ }^{1,2}$, Joo Shun $\operatorname{Tan}^{1 *}$ (D) Paramasivam Murugan ${ }^{1}$ and Rosma Ahmad ${ }^{1}$
}

\begin{abstract}
Background: The banana or scientifically referred to as Musa sp., is one of the most popular fruits all over the world. Almost all parts of a banana tree, including the fruits, stem juice, and flowers are commonly used as traditional medicine for treating diarrhoea (unripe), menorrhagia, diabetes, dysentery, and antiulcerogenic, hypoglycemic, antilithic, hypolipidemic conditions, plus antioxidant actions, inflammation, pains and even snakebites. The study carried out was to evaluate in vitro anti-urolithiatic activity from different types of Musa pseudo-stems.
\end{abstract}

Methods: Observing anti-urolithiathic activity via in vitro nucleation and aggregation assay using a spectrophotometer followed by microscopic observation. A total of 12 methanolic extracts were tested to determine the potential extracts in anti-urolithiasis activities. Cystone was used as a positive control.

Results: The results manifested an inhibition of nucleation activity $(0.11 \pm 2.32 \%$ to $55.39 \pm 1.01 \%)$ and an aggregation activity $(4.34 \pm 0.68 \%$ to $58.78 \pm 1.81 \%)$ at 360 min of incubation time. The highest inhibition percentage in nucleation assay was obtained by the Musa acuminate x balbiciana Colla cv "Awak Legor" methanolic pseudo-stem extract (2D) which was $55.39 \pm 1.01 \%$ at 60 min of incubation time compared to the cystone at $30.87 \pm 0.74 \%$. On the other hand,the Musa acuminate $x$ balbiciana Colla cv "Awak Legor" methanolic bagasse extract (3D) had the highest inhibition percentage in the aggregation assay incubated at 360 min which was obtained at $58.78 \pm 1.8 \% ; 5.53 \%$ higher than the cystone (53.25\%).The microscopic image showed a great reduction in the calcium oxalate ( $\mathrm{CaOx}$ ) crystals formation and the size of crystals in 2D and 3D extracts, respectively, as compared to negative control.

Conclusions: The results obtained from this study suggest that the extracts are potential sources of alternative medicine for kidney stones disease.

Keywords: Nucleation, Aggregation, Microscopic, Anti-urolithiathic, Musa pseudo-stem, Calcium oxalate

\footnotetext{
* Correspondence: jooshun@usm.my

${ }^{1}$ Bioprocess Technology Division, School of Industrial Technology, Universiti Sains Malaysia, 11800 Gelugor, Pulau Pinang, Malaysia

Full list of author information is available at the end of the article
}

(c) The Author(s). 2020 Open Access This article is licensed under a Creative Commons Attribution 4.0 International License, which permits use, sharing, adaptation, distribution and reproduction in any medium or format, as long as you give appropriate credit to the original author(s) and the source, provide a link to the Creative Commons licence, and indicate if changes were made. The images or other third party material in this article are included in the article's Creative Commons licence, unless indicated otherwise in a credit line to the material. If material is not included in the article's Creative Commons licence and your intended use is not permitted by statutory regulation or exceeds the permitted use, you will need to obtain permission directly from the copyright holder. To view a copy of this licence, visit http://creativecommons.org/licenses/by/4.0/. The Creative Commons Public Domain Dedication waiver (http://creativecommons.org/publicdomain/zero/1.0/) applies to the data made available in this article, unless otherwise stated in a credit line to the data. 


\section{Background}

Urinary stones are polycrystalline aggregates composed of various organic components and crystalline matrices. Lipids has been shown to be an important component in the stone matrix [21] where the stone matrix contributes only $2-3 \%$ of the dry weight [1] from urolith. The stone matrix contains various macromolecules such as protein (64\%), nonamino sugar (9.6\%), hexosamine as glucosamine (5\%), water-binding (10\%) and resting as ash [6].

The formation of stones because of lifestyle changes and nutritional factors is the most painful urology disease and becomes prevalent in the current population [29]. The characterization of stone formation or lithiasis is based on the formation of calculi, either nephrolithiasis or urolithiasis. Nephrolithiasis is a stone formation in the kidney while the formation of calculi in the bladder, ureter or any part along the urinary tract other than the kidney is known as urolithiasis [9]. Urologists often feel concerned with the problem of recurrent stone formation which neither successful lithotripsy nor surgery can prevent it. Moreover, the treatment of kidney stones is costly. This necessitates the need for finding alternate methods and valuable sources from natural or waste products.

Traditional remedies have been used for a long time in treating kidney stone disease. Most of the remedies used in traditional medicine systems are taken from plants although they do not have strong clinical evidences to support their causes. However, many remedies produced from plants have a positive effect on patients, especially some composite plants and herbal drugs such as Herniaria hirsuta where the extract can reduce the crystal size [3], Bergenia ligulata [40], Piper nigrum [23], Dolichos biflorus [12], Plantago major [45] etc. Previously, most of the studies were carried out in vivo using animal or human [27].

Synthetic drugs are a common substance widely used over the last decade and due to the unintended side effects of its use, it has been approved as safe and effective. However, it has been found that synthetic drugs have proven side effects as a result of long-term usage. Drugs such as Tamsulosin and nifedipine are opted for patients with kidney stones. Tamsulosin is an alpha-blocker that has the ability to relax the ureter, making urination easier, and for stones to pass through. Nifedipine is a calcium channel blocker. The expulsion rate differs across different drugs but was significantly high in tamsulosin (97.1\%), followed by nifedipine $(77.1 \%)$ and phloroglucinol $(64.3 \%)$ in a study done by Dellabella et al. [10]. Tamsulosin and nifedipine are drugs that have been validated with minor side effects on patients, and these include effects such as low blood pressure, headache, dizziness, and nausea [7]. Though generally acknowledged with minor side effects, Porpiglia et al. [31] reported adverse effects in a patient with transient hypotension and palpitations in the nifedipine treatment group and another patient with severe asthenia in the tamsulosin treatment group. Additionally, Islam et al. [17] reported only one patient who experienced serious effects associated with hypotension and palpitationsin the nifedipine treatment group. To come up with a solution for the effects caused by drugs when treating kidney stones, a safe alternative was introduced in this study from natural derivatives. Bananas have been known to have medicinal properties, especially in traditional medicine, and hence in this study, four different types of Musa variations were chosen to determine the potential extract on anti-urolithiasis in overcoming the kidney stone disease.

Banana cultivation generates a huge amount of biomass post-harvesting the fruits and these wastes include the pseudo-stems. Different parts of Musa pseudo-stems have been used traditionally for treating inflammation, high blood pressure, diabetics, diarrhoea, peptic ulcer, rheumatism, high blood pressure, burns, and wounds, as well as pseudo-stem in treating nephritis, uremia, and urolithiasis [19, 26, 28]. The banana cultivar Monthan corm extract has been reported to have antilithiatic potentials [18]. Despite the stated advantages, studies on banana pseudo-stems have not yet been explored extensively. Therefore, the aims of this study are to investigate the juice extraction and methanol extraction of pseudostems from 12 types of Musa species and determine their anti-urolithiasis activity via in vitro nucleation and aggregation assay followed by microscopic observation.

\section{Methods}

\section{Chemicals}

The chemicals used in this study include sodium oxalate, calcium chloride, potassium iodide, sodium chloride, sodium chloride and copper acetate (Bendosen, Selangor, Malaysia), methanol (Merck, Darmstadt, Germany), Tris and alpha-naphthol (Sigma -Aldrich, St. Louis, MO), cystone (Himalaya Herbal Healthcare, India), chloroform, hydrochloric acid, sodium hydroxide and bismuth sub-nitrate (R\&M Chemicals, Essex, United Kingdom), glacial acetic acid and sulphuric acid (QRëC, Republic of New Zealand), magnesium powder, ferric chloride, (HmbG Chemicals, Germany), gelatin (Srlchem, India) and copper sulphate (Univar Solution, China).

\section{Sample sources and preparation}

The inner core of different types of banana plants (Musa sp.) were collected and purchased from a local banana plantation located at Padang Serai, Kedah, Malaysia. The purchase was verbally agreed by the farmer. Four varieties of banana plants, named Musa acuminate x balbisiana Colla cv. 'Awak Manis' (A), M. paradisiaca cv. Nangka, 'Pisang Nangka' (B), Musa acuminate Colla cv. 'Sucrier' (C) and Musa acuminate x balbisiana Colla cv. 
'Awak Legor' (D) were selected in this study. The identification of the plant material was performed by a plant biotechnologist (Professor Dr. Sreeramanan Subramaniam) in Universiti Sains Malaysia. The voucher specimen of this material has not been deposited in any herbarium database. The outer surface of the pseudo-stems were cleaned with deionized water and cut into equivalent short segments for subsequent extraction processes.

\section{Extraction of banana pseudo-stem Juice extract}

The juice was extracted from a pseudo-stem by pressing using a sugarcane press machine (KT-160A, China, 750 $\mathrm{W}, 50 \mathrm{~Hz}$ ) [43], and this was done within $24 \mathrm{~h}$ after harvesting. The juice extracted was filtered to remove solid materials. The filtered juice was then freeze dried using a freeze dryer (Labconco, Missouri, USA) at the temperature of $-51{ }^{\circ} \mathrm{C}$ under a vacuum condition. The freeze-dried extracts were then labelled as $1 \mathrm{~A}$ to $1 \mathrm{D}$ according to the banana plant variety and stored in a $-20{ }^{\circ} \mathrm{C}$ freezer until further usage.

\section{Methanol extract of powdered pseudo-stem}

The pseudo-stem was later on freeze-dried and grinded into a powder form using a small electric dry mill (Philips, Amsterdam, Netherlands) before being transferred to a glass sealed container and placed in the refrigerator prior to the extraction process. The methanol extraction process was done according to Bantie et al. [4] with slight modifications. A total of $5 \mathrm{~g}$ of pseudo-stem powder was dispersed in $100 \mathrm{~mL}$ of $80 \%(\mathrm{v} / \mathrm{v})$ methanol at $25^{\circ} \mathrm{C}$ for $24 \mathrm{~h}$. After the soaking process, the pseudostem powder was filtered and evaporated using a rotary evaporator (Heidolph Rotary Evaporator, Laborota 4000, Schwabach, Germany) at a temperature not exceeding $40{ }^{\circ} \mathrm{C}$. The extracts were labelled as $2 \mathrm{~A}$ to $2 \mathrm{D}$ according to the banana plant variety, and were then freeze dried and stored in $\mathrm{a}-20^{\circ} \mathrm{C}$ freezer until further needed.

\section{Methanol extract of bagasse}

The pseudo-stem after the juice pressing was used as bagasse. Approximately, $5 \mathrm{~g}$ of dry bagasse was soaked in $100 \mathrm{~mL}$ of $80 \%(\mathrm{v} / \mathrm{v})$ methanol at $25^{\circ} \mathrm{C}$ for $24 \mathrm{~h}$. After the soaking process, the extract was filtered using a Whatman No.1 filter paper and the filtrate was concentrated using a rotary evaporator at a temperature not exceeding $40{ }^{\circ} \mathrm{C}$. The extract was then freeze dried and stored in again in the $-20^{\circ} \mathrm{C}$ freezer until usage. The extracts were labelled as $3 \mathrm{~A}$ to $3 \mathrm{D}$ according to the banana plant variety.

\section{Estimation of yield extract}

The yield of extract (extractable components) was calculated from the following equation:

$$
\begin{aligned}
\text { Yield }(\%)= & (\text { wt. of dry extract/wt. of dry plant }) \\
& \times 100
\end{aligned}
$$

\section{Nucleation assay}

A nucleation assay was carried out according to the method as described by Rajeswari et al. [33] and Sujatha et al. [42] with some modifications. Calcium chloride $(4 \mathrm{mmol} / \mathrm{L})$ and sodium oxalate $(7.5 \mathrm{mmol} / \mathrm{L})$ solution were prepared in a Tris buffer (Tris $0.05 \mathrm{~mol} / \mathrm{L}$ and $\mathrm{NaCl} 0.15 \mathrm{~mol} / \mathrm{L}$ ) at $\mathrm{pH}$ 6.5. A volume of $95 \mu \mathrm{L}$ calcium chloride solution was added to $10 \mu \mathrm{L}$ of $2 \mathrm{mg} / \mathrm{ml}$ of extracts in 96-well plates. Sodium oxalate $(95 \mu \mathrm{L})$ was then added into the mixture to induce the reaction of crystallization. The mixture was maintained at $37^{\circ} \mathrm{C}$. The nucleation activity was estimated by comparing the optical density in the presence of distilled water with that of negative control. Cystone was used as positive control. The inhibition reaction was measured at an absorbance of $620 \mathrm{~nm}$ using a microplate reader (Tecan Sunrise, Switzerland) for 0, 30, 60, 180 and $360 \mathrm{~min}$ and the percentage inhibition of nucleation was calculated based on Eq. 1. The experiment was done in triplicate.

\section{Aggregation assay}

The aggregation of the calcium oxalate $(\mathrm{CaOx})$ crystals was determined by the method of Hess et al. [15] and Saha \& Verma [36] with a slight modification. The CaOx monohydrate $(\mathrm{COM})$ crystals were prepared by mixing calcium chloride $(50 \mathrm{mmol} / \mathrm{L})$ and sodium oxalate $(50$ $\mathrm{mmol} / \mathrm{L})$. Both solutions were equilibrated in a water bath for $1 \mathrm{~h}$ at $60^{\circ} \mathrm{C}$ for the formation of COM crystals. The crystals were cooled to $37^{\circ} \mathrm{C}$ prior to evaporation. The COM crystals were prepared at a final concentration of $0.8 \mathrm{mg} / \mathrm{mL}$ in a Tris buffer (Tris $0.05 \mathrm{~mol} / \mathrm{L}$ and $\mathrm{NaCl}$ $0.15 \mathrm{~mol} / \mathrm{L}$ ) at $\mathrm{pH} 6.5$. A $100 \mu \mathrm{L}$ of extracts were added to the COM crystals solution and incubated at $37^{\circ} \mathrm{C}$ for 360 min. The aggregation activity was estimated by the turbidity using a microplate reader (Tecan Sunrise, Switzerland) in the presence of the extract compared to the control by measurement at $620 \mathrm{~nm}$ for $0,30,60,180$ and $360 \mathrm{~min}$. The experiment was done in triplicate.

The percentages inhibition of nucleation and aggregation were calculated as below:

$$
\left.\% \text { of inhibition }=\left[\left(\mathrm{OD}_{\text {control }} / \mathrm{OD}_{\text {test }}\right)\right] / \mathrm{OD}_{\text {control }}\right] * 100
$$

\section{Microscopic observation}

The samples obtained from nucleation and aggregation assays were observed under an inverted microscope (Optika, Italy) equipped with a digital camera at $10 \mathrm{X}$ 
magnification to visualize the calcium oxalate crystals formation and inhibition.

\section{Phytochemicals test}

A total of $1 \mathrm{~g}$ of 2D pseudo-stem and 3D bagasse extracts were separately dissolved in $100 \mathrm{~mL}$ of $80 \%(\mathrm{v} / \mathrm{v})$ methanol solvents for stock solution in phytochemical screening according to standard methods [13] as briefed below:

\section{Test for alkaloids}

The detection of alkanoids in qualitative chemical tests are due to the character of alkanoids being susceptible to precipitation as salts of organic acids or with the compound of heavy metals like $\mathrm{Hg}, \mathrm{Au}, \mathrm{Pt}$, etc. A total of $50 \mathrm{mg}$ of samples was dissolved in $5 \mathrm{ml}$ of distilled water. The solution was added with $2 \mathrm{M}$ hydrochloric acid until an acid reaction occurred and then filtered. The filtrate was tested for the presence of alkaloids as detailed below:

Dragendorff's Test: Approximately $2 \mathrm{ml}$ of the filtrate was added with $1 \mathrm{ml}$ of Dragendorff's reagent along the side of the test tube. The formation of orange or an orange to reddish-brown precipitate indicates the test as being positive.

\section{Test for flavonoids}

Shinoda's test: A piece of magnesium followed by concentrated hydrochloric acid was added to a stock solution, with the acid being added by drops, and heated. The appearance of magenta colouration shows the presence of flavonoids.

Alkaline Reagent Test: Approximately 5 drops of 5\% sodium hydroxide was added into $1 \mathrm{ml}$ of stock solution which resulted in an increase in the intensity of a yellow hue which later on becomes colourless upon the addition of a few drops of $2 \mathrm{M}$ hydrochloric acid. This also indicates the presence of flavonoids.

$\mathrm{Zn} / \mathrm{HCl}$ or $\mathbf{M g} / \mathrm{HCl}$ Reduction: A few fragments of a magnesium ribbon and concentrated hydrochloric acid was added to a stock solution, with the acid being added by drops. The presence of flavanol glycosides was inferred by the development of a pink to crimson colour.

\section{Test for tannins}

Ferric chloride Test: A few drops of neutral 5\% ferric chloride solution were added into a stock solution. A dark green colour indicates the presence of phenolic hydroxyl group compounds.

Gelatin Test: Approxiately $2 \mathrm{ml}$ of $1 \%$ gelatin solution containing $10 \%$ sodium chloride was added into a stock solution. A white precipitate indicates the presence of phenolic compounds.

\section{Test for saponins}

Foam test: A small amount of stock solution was shaken with a small quantity of water. A persisting foam suspension (for about $10 \mathrm{~min}$ ) indicates the presence of saponins.

\section{Test for steroids}

Approximately $1 \mathrm{mg}$ of 2D pseudo-stem / 3D bagasse extract was dissolved with $10 \mathrm{~mL}$ of chloroform and concentrated sulphuric acid $(10 \mathrm{~mL})$ in test tube. The upper layer in the test tube was turns into red and sulphuric acid layer will show yellow with green fluorescence which indicates the presence of steroids.

\section{Test for triterpenoids}

Salkowski test: A total of $5 \mathrm{ml}$ of each stock solution was mixed in $2 \mathrm{~mL}$ of chloroform and then followed by adding $3 \mathrm{~mL}$ of concentrated $\mathrm{H}_{2} \mathrm{SO}_{4}$ carefully to form a layer. A reddish-brown colouration formed in the inter face shows positive results for the presence of terpenoids.

\section{Test for carbohydrates}

Molisch's test: A total of $1 \mathrm{ml}$ of stock solution was added with a few drops of $1 \%$ alpha-napthol and 2-3 ml concentrated sulfuric acid along the side of the test tube. A reddish-violet or purple ring was formed at the junction of two liquids which thus confirms the test.

Barfoed's test: $2 \mathrm{ml}$ of reagent was added to $2 \mathrm{ml}$ of the stock solution, mixed and then placed in a boiling water bath for $1 \mathrm{~min}$. A red precipitate formed indicates the presence of monosaccharides.

\section{Test for proteins}

Biuret test: To $2 \mathrm{ml}$ of the test solution, 5 drops of $1 \%$ copper sulphate solution and $2 \mathrm{ml}$ of $10 \%$ Sodium hydroxide $(\mathrm{NaOH})$ were added. After mixing thoroughly, the purple or violet hue formed confirmed the presence of proteins.

\section{Statistical analysis}

All the experiments were performed in triplicates. The data obtained were analysed by two-way ANOVA and Tukey's multiple comparison test wherever necessary. A value of $p<0.05$ was considered significant in all cases.

\section{Results}

Physical characteristics of banana pseudo-stem extracts

The physical characteristics of banana pseudo-stem extracts after being freeze dried are shown in Table 1. The juice extracts of $1 \mathrm{~A}$ to $1 \mathrm{C}$ exhibit a dark brown colour but 1D had a yellowish colour. The juice extracts of 1B to $1 \mathrm{D}$ were sticky. The methanol extract of powdered in 2B was fluffy and white in colour while the others (2A, 
Table 1 Physical characteristics of banana pseudo-stem extracts after freeze dried. Musa acuminate x balbisianaColla cv. 'Awak Manis' (A), M. paradisiaca cv. Nangka, 'Pisang Nangka' (B), Musa acuminate Colla cv. 'Sucrier' (C) and Musa acuminate $\mathrm{x}$ balbisianaColla cv. 'AwakLegor' (D)

\begin{tabular}{llll}
\hline Label & Extracts & Characteristics & Yield (\%, w/w) \\
\hline IA & Juice & Dark brown, solid & $0.07 \pm 0.02$ \\
IB & Juice & Dark brown, sticky & $0.05 \pm 0.05$ \\
1C & Juice & Dark brown, sticky & $0.07 \pm 0.01$ \\
ID & Juice & Yellowish, sticky & $0.11 \pm 0.06$ \\
2A & Pseudo-stem & Brown, sticky & $0.86 \pm 0.12$ \\
2B & Pseudo-stem & White, fluffy & $1.64 \pm 0.27$ \\
2C & Pseudo-stem & Brown, sticky & $3.11 \pm 0.15$ \\
2D & Pseudo-stem & Brown, sticky & $5.01 \pm 0.11$ \\
3A & Bagasse & Light yellow, fluffy & $0.95 \pm 0.08$ \\
3B & Bagasse & Brown, sticky & $0.57 \pm 0.04$ \\
3C & Bagasse & Brown, sticky & $0.80 \pm 0.11$ \\
3D & Bagasse & Brown, sticky & $0.96 \pm 0.13$ \\
\hline
\end{tabular}

$2 \mathrm{C}$ and 2D) were brown and sticky. Similarly, most of the methanol extracts of bagasse pseudo-stems were brown and sticky except $3 \mathrm{~A}$ which was light yellow and fluffy. In the extraction, the highest yield of extract was obtained from the 2D pseudo-stemat $5.01 \%$ followed by the 2C pseudo-stem (3.11\%), 2B pseudo-stem (1.64\%), 3D bagasse $(0.96 \%), 3 \mathrm{~A}$ bagasse $(0.95 \%), 2 \mathrm{~A}$ pseudostem $(0.86 \%), 3 \mathrm{C}$ bagasse $(0.80 \%)$, and $3 \mathrm{~B}$ bagasse $(0.57 \%)$. All juice extracts show lower percentages of yield, all less than $0.1 \%$.

\section{Effect of inhibition in nucleation assay}

The effects of inhibition of nucleation activities for different extracts are presented in Fig. $1(\mathrm{a}, \mathrm{b}$ and $\mathrm{c})$. The results in Table 2 indicate a statistically significant difference $(p<0.0001)$ between two factors, the type of extract and incubation time to the percentage of inhibition activity of 13 samples. The highest inhibition of nucleation activity was obtained from the 2D extract (methanol extract from Musa acuminate x balbisiana Colla cv. 'Awak Legor'). The inhibition activity in 2D bagasse extract reached the highest inhibition of $55.39 \pm 1.01 \%$ at 60 min of incubation, which was $24.52 \%$ higher than the positive control, cystone $(23.02 \pm 3.35 \%)$. At $360 \mathrm{~min}$ of incubation, the percentage of inhibition obtained from the $2 \mathrm{D}$ bagasse extract remained stable at $54.00 \pm 2.72 \%$ while the positive control (cystone) reduced to23.02 $\pm 3.35 \%$. All the extracts showed increasing trends in inhibition activities from 0 to $60 \mathrm{~min}$, followed by a stagnant phase or reduction in the inhibition activities at 180 min except for the $1 \mathrm{C}, 2 \mathrm{~A}, 2 \mathrm{~B}$ and $3 \mathrm{~B}$ extracts. The second highest inhibition of nucleation activity exceeds $50 \%$ and was from the $2 \mathrm{C}$ pseudo-stem extract (methanolic extract from Musa acuminate Collacv. 'Sucrier'), which was $51.57 \pm 0.42 \%$ incubated at $360 \mathrm{~min}$. The results obtained from the nucleation assay confirmed that the extract has nucleation-preventing agents which will prevent the growth of kidney stones.

\section{Effect of inhibition in aggregation assay}

The effects of inhibition of aggregation activities for different extracts were presented in Fig. 2(a, b and c) with a statistically significant difference $(p<0.0001)$ between of the two factors which are type of extract and incubation time to percentage of inhibition activity of 13 samples (Table 3 ). The 3D extracts from Musa acuminate $\mathrm{x}$ balbisiana Colla cv. 'Awak Legor' bagasse showed the highest percentage of inhibition of aggregation activities as compared to other extracts and positive control (cystone). Cystone had $42.89 \pm 2.34 \%$ of inhibition while the 3D bagasse extract only had $28.67 \pm 1.33 \%$ of inhibition at $0 \mathrm{~min}$. However, the percentage of inhibition in the 3D bagasse extract increased to58.78 $\pm 1.81 \%$, which was $5.53 \%$ higher than cystone $(53.25 \pm 2.71 \%)$ after $360 \mathrm{~min}$ of incubation. The inhibition of aggregation activities of other extracts did not exceed $50 \%$, which is considerably low when compared to cystone. For $2 \mathrm{C}$ and 2Dpseudo-stemextracts, the inhibition of aggregation activities was only obtained at $37.67 \pm 1.80 \%$ and $35.11 \pm 1.37 \%$, respectively. The lowest percentage of inhibition was from the $3 \mathrm{C}$ bagasse extract after $360 \mathrm{~min}$ of incubation at $37^{\circ} \mathrm{C}(4.34 \pm 0.68 \%)$. The $3 \mathrm{D}$ extract was chosen for the microscopic study given its percentage of inhibition.

\section{Microscopy study on the changes of CaOx crystals in nucleation and aggregation assays}

The nucleation and aggregation activities were validated by observing the $\mathrm{CaOx}$ crystals' changes under an inverted microscope at 10X magnification. Figure $3(\mathrm{a}, \mathrm{b}$, and $\mathrm{c})$ show the percentage of the inhibition of nucleation in nucleation assay by the $2 \mathrm{D}$ pseudo-stem extract as compared to the negative control and positive control (cystone). It is evident that the 2D pseudo-stem extract and cystone caused the dissolution of $\mathrm{CaOx}$ crystal nucleation as the $\mathrm{CaOx}$ crystals were less dense as compared to the negative control (Fig. 3), revealing that the 2D pseudo-stem extracts could prevent the reaction of calcium chloride and sodium oxalate from forming $\mathrm{CaOx}$ crystals, indicative of antilithiatic activity. Figure 4(a,b and c) show the microscopic images of aggregation inhibition activities of the 3D bagasse extract, negative control and positive control. The number and morphology of the $\mathrm{CaOx}$ crystals showed that the3D extract at its higher concentration $(2 \mathrm{mg} / \mathrm{ml})$ had a greater potential towards crystal aggregation inhibition. The reduction on the size of crystals could be observed in the 3D bagasse extract, indicating the potential of the extracts in reducing stone sizes. The extract of 


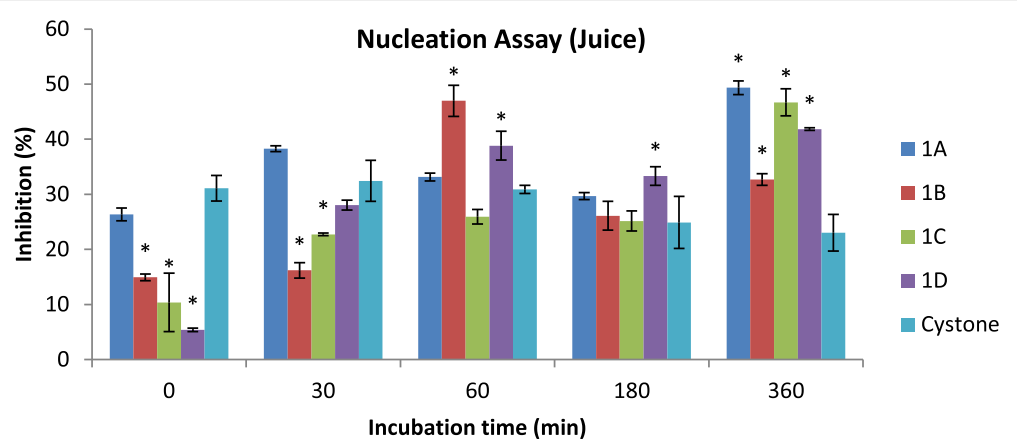

(a)

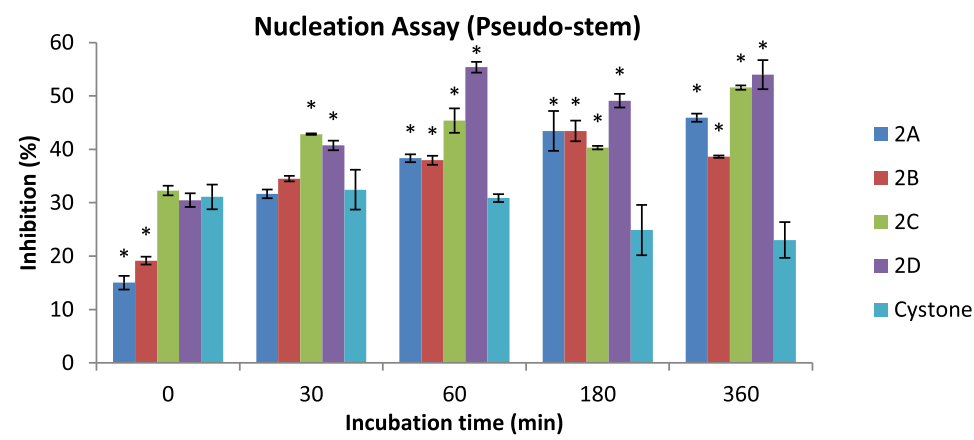

(b)

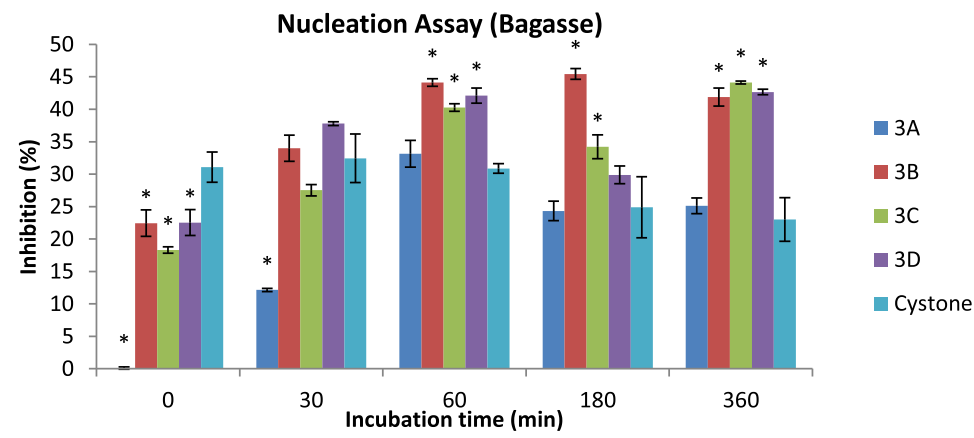

(c)

Fig. 1 Nucleation assay of 12 extracts and positive control (cystone) incubated at $37^{\circ} \mathrm{C}$ for 360 min. a Juice (b) Pseudo-stem (c) Bagasse. The interaction term between types of extracts and incubation time was significant $(p<0.0001)$, repeated-measures two-way analysis of variance, adjusted for multiple pairwise comparisons with the Tukey's multiple comparison test, was applied to these data to assess differences at each time interval. Points at the same time interval and bars with aesrick (*) are significantly different from control (Cystone), $p<0.05$

Table 2 Two-way ANOVA analysis of two main factors (incubation time and types of extracts) related to Caox crystal inhibition activity in nucleation assay

\begin{tabular}{lllllll}
\hline Source & Dependent variable & SS & Df & MS & F (DFn, DFd) & P value \\
\hline Interaction & Inhibition activity & 5705 & 48 & 118.9 & $F(48,130)=38.95$ & $P<0.0001$ \\
Incubation time & Inhibition activity & 12147 & 4 & 3037 & $F(4,130)=995.3$ & $P<0.0001$ \\
Types of extracts & Inhibition activity & 9038 & 12 & 753.2 & $F(12,130)=246.8$ & $P<0.0001$ \\
\hline
\end{tabular}




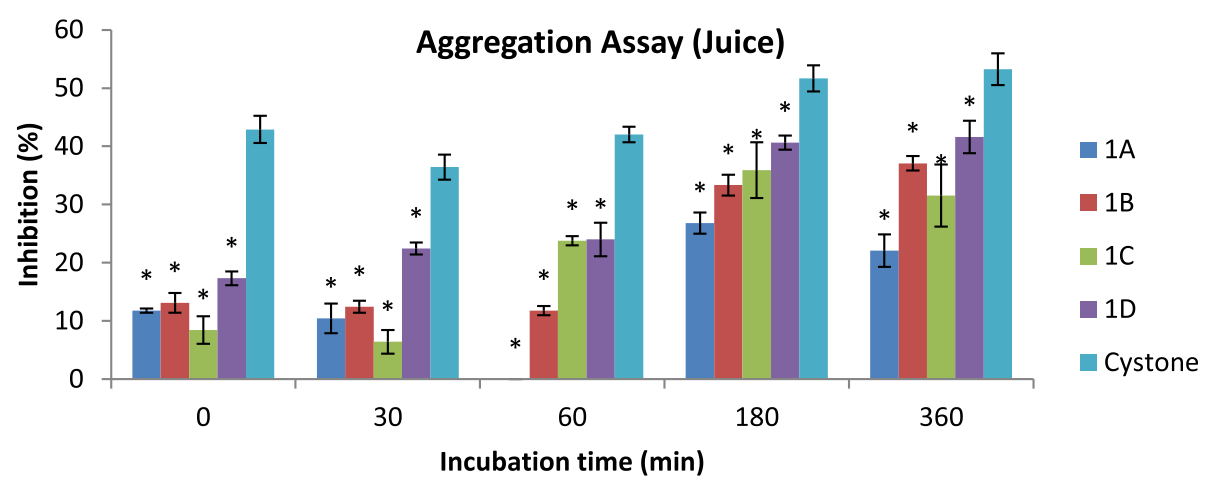

(a)

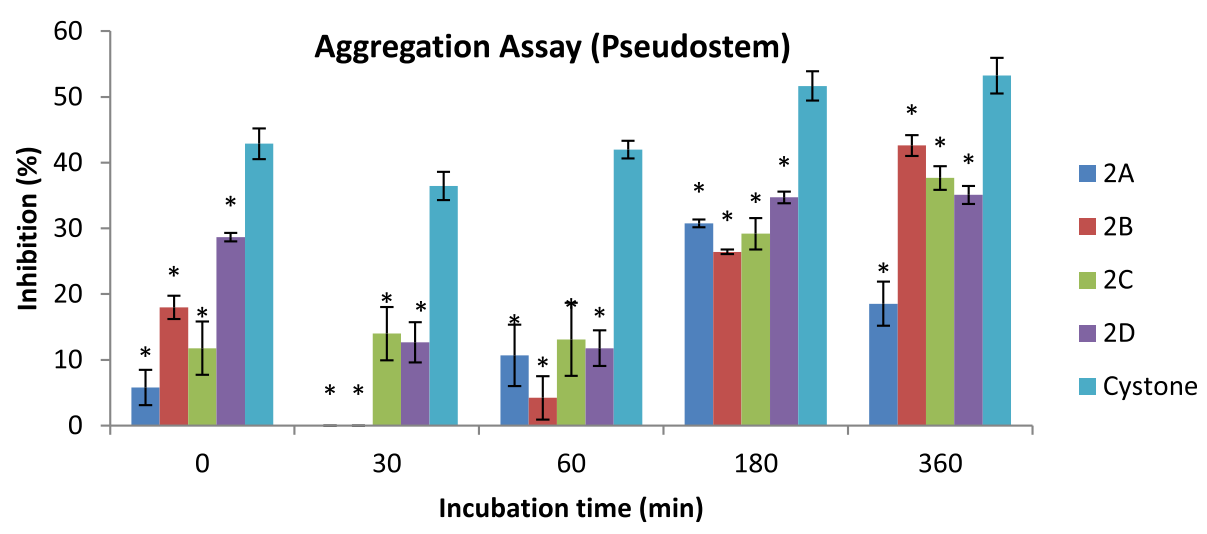

(b)

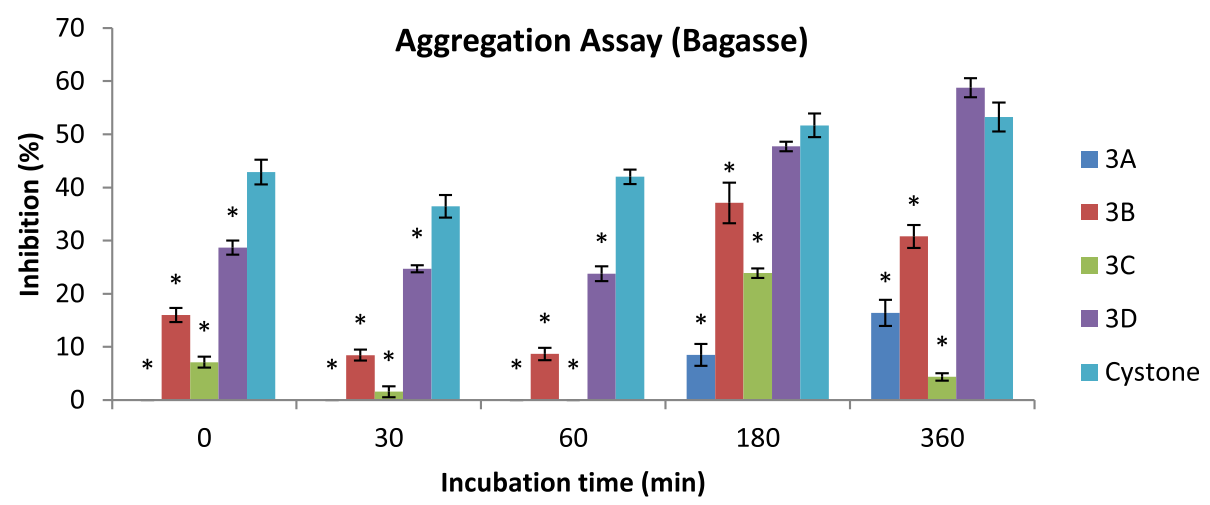

(c)

Fig. 2 Aggregation assay of 12 extracts and positive control (cystone) incubated at $37^{\circ} \mathrm{C}$ for $360 \mathrm{~min}$. a Juice (b) Pseudo-stem (c) Bagasse. The interaction term between types of extracts and incubation time was significant $(p<0.0001)$, repeated-measures two-way analysis of variance, adjusted for multiple pairwise comparisons with the Tukey's multiple comparison test, was applied to these data to assess differences at each time interval. Points at the same time interval and bars with aesrick $\left(^{*}\right)$ are significantly different from control (Cystone), $p<0.05$ 
Table 3 Two-way ANOVA analysis of two main factors (incubation time and types of extracts) related to Caox crystal inhibition activity in aggregation assay

\begin{tabular}{lllllll}
\hline Source & Dependent variable & SS & Df & MS & F (DFn, DFd) & $P$ value \\
\hline Interaction & Inhibition activity & 4924 & 48 & 102.6 & $F(48,130)=20.37 \quad P<0.0001$ \\
Incubation time & Inhibition activity & 17809 & 4 & 4452 & $F(4,130)=884.3 \quad P<0.0001$ \\
Types of extracts & Inhibition activity & 22087 & 12 & 1841 & $F(12,130)=365.6 \quad P<0.0001$ \\
\hline
\end{tabular}

Musa acuminate x balbisiana Colla cv. 'Awak Legor' exhibited good nucleation and aggregation activities compared to other types of Musa plants.

\section{Phytochemicals test for 2D pseudo-stem and 3D bagasse extracts}

In the present study, a preliminary phytochemical analysis led to the discovery of metabolites in the 2D pseudo-stem and 3D bagasse extracts of Musa acuminate x balbisiana Colla cv. 'Awak Legor' (Table 4). Both selected extracts show similar metabolites compositions containing saponin, tannins, flavonoids, steroid, carbohydrate, triterpenoid except in Shinoda's test where the 3D bagasse extracts provided a negative result.

\section{Discussion}

All parts of a banana plant/tree have been widely used in traditional medicine since many earlier times [37]. Among the most potential parts is the pseudo-stem which has a layer of leaf sheaths and is rich in nutrients including sugars, starch, minerals, dietary fibre, and antioxidant compounds [16]. This study has provided a preliminary scientific evidence that Musa pseudo-stem extracts especially from Musa acuminate $x$ balbisiana Colla cv. 'Awak Legor' possess lithotripsy properties. Although the exact mechanism of stone formation cannot be fully understood, the formation is most commonly described to occur through a series of physiochemical events of supersaturation, nucleation, growth, aggregation and retention in kidney tubules [34]. Nucleation is the first step of renal stone formation where it establishes the smallest unit lattice of a crystal species, and is divided into two types of nucleation; homogeneous nucleation and heterogeneous or secondary nucleation [44].

Aqueous methanol is commonly used as an extraction solvent alone in plant extraction. Methanol is useful for extracting polar analytes due to its excellent hydrogen bond donating and accepting properties. The addition of aqueous properties to the organic solvent significantly increased the extract yields. It could be suggested that more phenolic compounds and other bioactive molecules could be obtained with an increase of polarity of the organic solvents with the addition of water [38]. Most of the extracts show similar physical characteristics, all brown and sticky. The stickiness is mainly due to the presence of low molecular weight sugars such as fructose, glucose or sucrose [35]. A study by Akpabio et al. [2] showed that Musa paradisiaca and Musa sapientum pseudo-stem wastes contain high amount of carbohydrates at 62.21 and $93.82 \mathrm{mg} / 100 \mathrm{~g}$, while sugar contents at 28.60 and $29.76 \mathrm{mg} / 100 \mathrm{~g}$, respectively. Further study of the selected extracts will be done to characterize the bioactive compounds and the composition of the extracts.

In this study, cystone was chosen as a positive control to compare the inhibition of nucleation and aggregation activities. Cystone has been designed and developed for the management of urolithiasis and renal calculi disease; it is a formulation of several herbs such as Didymocarpus pedicellata, Saxifraga ligulata and Gokshura [20]. This product has been used since 1943 to treat urolithiasis and urinary tract infections. In the study of Palaniyamma and Jeyaraman [25], cystone was used as a standard and exerted a significant decrease on the renal calculi and calculi size from $6.82 \pm 2.03$ to $2.91 \pm 2.31 \mathrm{~mm}$ $(p<0.001)$. Similarly, Sharma et al. [39] and Chaudhary et al. [8] studied the leaf extracts for inhibition of calcium oxalate by using cystone as a control in their experiments.

Nucleation is an important first step for the initiation of crystals, which then grow and form aggregates. Hence, in vitro crystallization study was carried out to screen the ability of calcium oxalate inhibition from different Musa pseudo-stem extracts. The results of the nucleation assay confirmed that the extract contained nucleation-preventing agents and aggregation-preventing agents. The Musa extracts may contain substances such as saponin that inhibit the growth of $\mathrm{CaOx}$ crystals [24]. A saponin-rich fraction of Herniaria hirsuta was also found to be a potent inhibitor of $\mathrm{CaOx}$ crystal formation in vitro [11]. However, the contribution of other phytochemicals on the reported activities cannot be excluded.

Controlling the crystallization process is the most important for the stone formation, i.e. the nucleation is the best way to prevent and treat urolithiasis. This can be achieved by using plant extracts like Musa pseudo-stem since they have been widely used in folk and Ayurveda medicine to treat kidney stones. Generally, plant extracts consist of unique mixture of numerous bioactive compounds which can be extracted with various extraction techniques [41]. In this study, the Musa acuminate $x$ balbisiana Colla cv. 'Awak Legor' pseudo-stem extract showed a percentage of inhibition of nucleation which was 
(A)

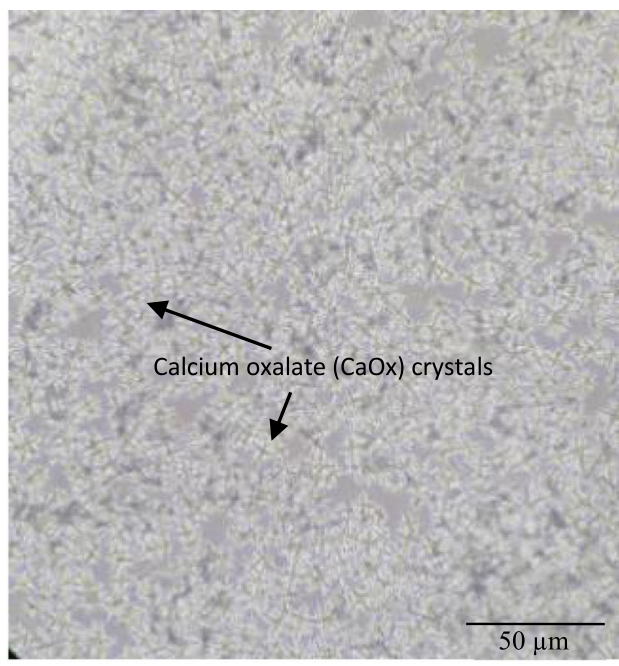

(B)

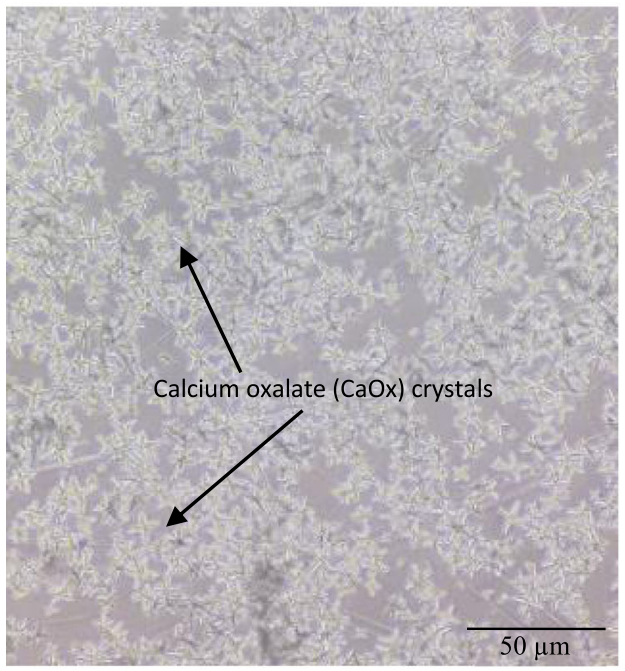

(C)

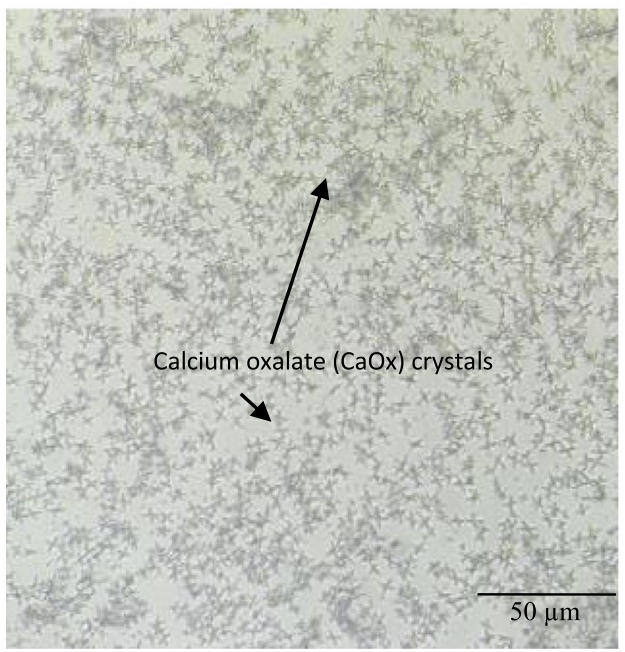

Fig. 3 Light microscopic image of nucleation inhibition activity (10X magnification) (a) negative control (no treatment) (b) positive control (cystone) $(2 \mathrm{mg} / \mathrm{mL})(\mathbf{c}) 2 \mathrm{D}$ extract $(2 \mathrm{mg} / \mathrm{mL})$

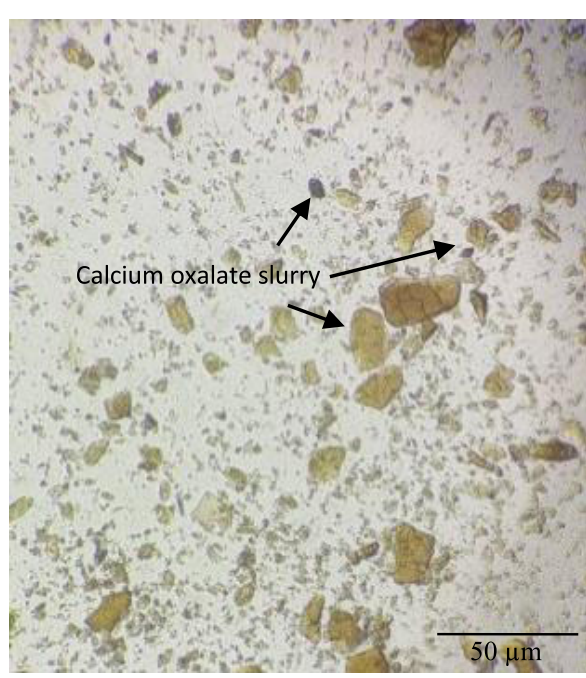

(A)

(B)
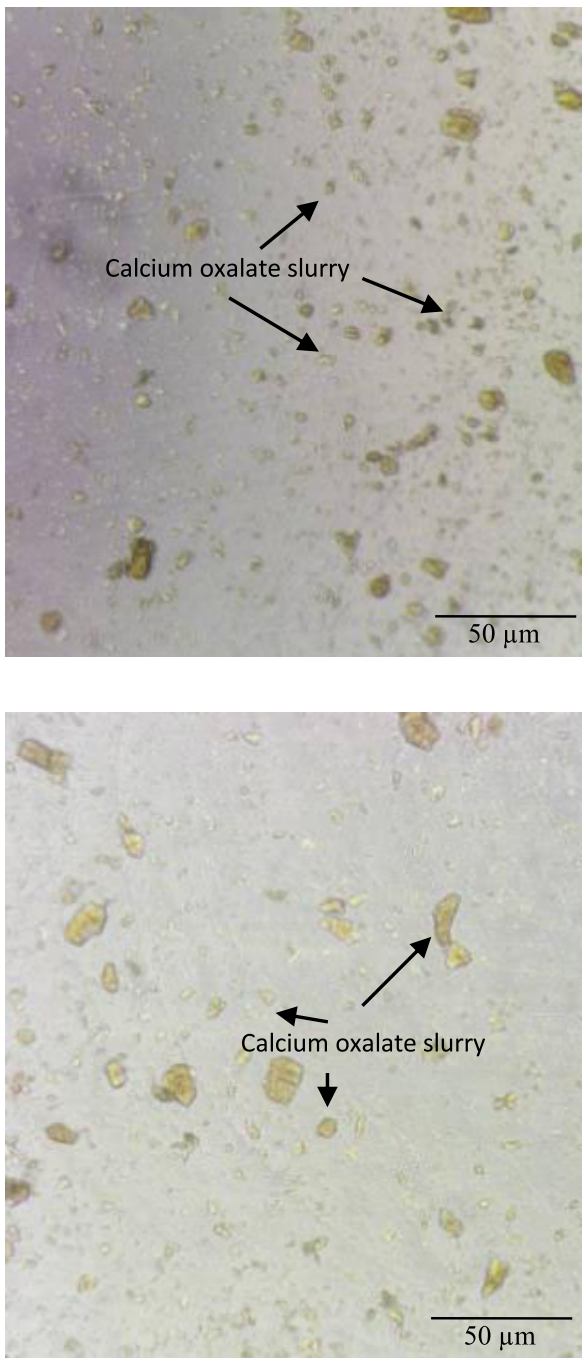

Fig. 4 Light microscopic image of aggregation inhibition activity (10x magnification). a negative control (no treatment) (b) positive control (cystone) $(2 \mathrm{mg} / \mathrm{mL})(\mathbf{c}) 3 D$ extract $(2 \mathrm{mg} / \mathrm{mL})$ 
Table 4 Phytochemicals test for 2D pseudo-stem and 3D bagasse extracts

\begin{tabular}{|c|c|c|}
\hline Sample/Test & $2 \mathrm{D}$ & $3 D$ \\
\hline \multicolumn{3}{|l|}{ Saponin } \\
\hline - Foam test & + & + \\
\hline \multicolumn{3}{|l|}{ Tannins } \\
\hline - Gelatin test & + & + \\
\hline \multicolumn{3}{|l|}{ - Ferric chloride test } \\
\hline \multicolumn{3}{|l|}{ Flavonoids } \\
\hline - Shinoda's test & + & - \\
\hline - Alkaline reagent test & + & + \\
\hline - $\mathrm{Zn} / \mathrm{HCl}$ or $\mathrm{Mg} / \mathrm{HCl}$ reduction & - & - \\
\hline Steroid & + & + \\
\hline \multicolumn{3}{|l|}{ Carbohydrate } \\
\hline - Molisch's test & + & + \\
\hline - Barfoed's test & + & + \\
\hline Triterpenoids & + & + \\
\hline \multicolumn{3}{|l|}{ Protein } \\
\hline - Biuret test & - & - \\
\hline \multicolumn{3}{|l|}{ Alkaloid } \\
\hline - Dragendorff's test & - & - \\
\hline
\end{tabular}

+ Positive result, - negative result

confirmed by the reduction in optical density value compared to the negative control (without treatment) after $6 \mathrm{~h}$ of incubation. An increase in optical density at $620 \mathrm{~nm}$ with time is related to the crystal growth [14]. The inhibition of crystal formations can also be demonstrated through a visual observation under an inverted microscope and then comparing the microscopic image with a negative control (No treatment). A previous finding by Kalpana et al. [18] showed that the ethanolic extract of banana cultivar Monthan could inhibit crystal nucleation, growth and aggregation at concentrations of 50-1600 $\mu \mathrm{g}$.

Musa pseudo-stem extracts also showed an ability in size decrement through aggregation assay. Aggregation is the second most important factor in kidney stone formations where it is the mechanism increasing the size of particles, composition and structure of urinary stones [22]. The crystals which adhered to each other are not easily separated and held in place. This process plays an important role in lithiasis [18]. Various plant extracts showed the ability to dissolve calcium oxalate crystals in aggregation assay. Examples include species such as Daucus carota [5], Bryophyllum pinnatum and Ocimum gratissimum [30], Ipomoea batatas leaves and roots [32], Musa parasidiaca pseudo-stem [26], etc. The results obtained from this study confirmed that the pseudo-stem extract of Musa acuminate $x$ balbisiana Colla cv. 'Awak Legor' is quite promising for further studies.
Plants have the ability to synthesize almost an unlimited number of substances and in many cases, these chemicals serve in plant defence mechanisms against microorganisms, insects, and herbivores. Generally, any part of a plant may contain various active ingredients. Qualitative analysis of crude extracts plays a very important role in identifying the purity and quality of drug likeliness. Generally, the identification of the presence of secondary metabolites produced in response to biotic or abiotic stress in the plants crude extracts will be done by using preliminary phytochemical screening method. The presence of saponins, flavonoid, tannins, triterpenoid, steroid and carbohydrate was discovered in both selected extracts. However, the 3D bagasse extracts only showed positive results in the Alkaline Reagent Test compared to the $2 \mathrm{D}$ pseudo-stem extracts, though both test assays indicated the presence of flavonoids. Flavonoids are a group of plant metabolites thought to provide health benefits through cell signalling pathways and antioxidant effects. These molecules are found in a variety of fruits and vegetables. Flavonoids are polyphenolic compounds comprising 15 carbon atoms that are soluble in water, which consists of two benzene rings bound by a short three carbon chain. It can be divided into six major subtypes, including chalcones, flavones, isoflavonoids, flavanones, anthoxanthins and anthocyanins. Negative results obtained by the 3D bagasse extracts in Shinoda' test assay is probably due to the low concentration of flavonoids metabolites which would only give positive results in an alkaline reagent test. The unique test results are probably the main reason why $2 \mathrm{D}$ pseudo-stem extracts obtained a higher percentage of nucleation assays while the 3D bagasse extracts obtained a higher aggregation assay. Further analysis using liquid chromatography mass spectrometry (LCMS) will be done to confirm the presence of metabolites in both selected extracts.

\section{Conclusion}

The findings of the present study also highlight the ability of different types of Musa extracts to prevent the nucleation and aggregation of calcium oxalate crystals as proved in in vitro studies. These data suggest that the presence of antiurolithic effects in the Musa extracts is possibly due to calcium oxalate crystal inhibition, and further pre-clinical and clinical studies are needed to evaluate and establish the use of Musa acuminate $x$ balbisiana Colla cv. 'Awak Legor' pseudo-stem extracts as antiurolithiatic activity.

\section{Abbreviations \\ CaOx: Calcium oxalate; COM: Calcium oxalate monohydrate; ANOVA: Analysis of variance}

\section{Acknowledgements}

The author (Mazni Abu Zarin) would like to express her deepest appreciation and gratitude to Universiti Sains Malaysia for providing her an opportunity to 
pursue a PhD programme. A great deal of thanks goes to the staff of the School of Industrial Technology, especially the laboratory assistants, who have been very helpful in providing equipment assistance and meeting all laboratory needs without fail.

\section{Authors' contributions}

MAZ performed the experiments from sample preparation, extraction and analysis. She was a major contributor in writing the manuscript. TJS interpreted the data and revised the manuscript. PM helped to analyse the data. RA provided suggestions in the experiment design. All authors read and approved the final manuscript.

\section{Funding}

Not applicable.

\section{Availability of data and materials}

All data generated or analysed during this study are included in this published article.

\section{Ethics approval and consent to participate}

Not applicable.

\section{Consent for publication}

Not applicable.

\section{Competing interests}

The authors declare that they have no competing interests.

\section{Author details}

'Bioprocess Technology Division, School of Industrial Technology, Universit Sains Malaysia, 11800 Gelugor, Pulau Pinang, Malaysia. ²Laboratory Vaccines and Immunotherapeuthics, Institute of Bioscience, Universiti Putra Malaysia, UPM Serdang, 43400 Serdang, Selangor, Malaysia.

\section{Received: 19 December 2019 Accepted: 9 October 2020}

\section{Published online: 19 October 2020}

\section{References}

1. Aggarwal KP, Narula S, Kakkar M, Tandon C. Nephrolithiasis: molecular mechanism of renal stone formation and the critical role played by modulators. Bio Med Res Int. 2013;2013:1-21. https://doi.org/10.1155/2013/ 292953.

2. Akpabio UD, Udiong DS, Akpakpan AE. The physicochemicals characteristics of plantain (Musa paradisiaca) and banana (Musa sapientum ) pseudostem wastes. Adv Nat Appl Sci. 2012;6(2):167-72.

3. Atmani F, Khan SR. Effects of an extract from Herniaria hirsute on calcium oxalate crystallization in vitro. BJU Int. 2000;85(6):621-5.

4. Bantie L, Assefa S, Teklehaimanot T, Engdawork E. In Vivo antimalarial activity of the crude leaf extract and solvent fractions of Croton macrostachyus Hocsht. (Euphorbiaceae) against $P$. berghei in mice. BMC Complement Altern Med. 2014;14(1):1-10.

5. Bawari S, Negi-Sah A, Tewari D. Antiurolithiatic activity of Daucus carota: an in vitro study. Pharmacogn J. 2018;10(5):880-4

6. Boyce WH. Organic matrix of human urinary concretions. Am J Med. 1968; 45:673-83

7. Cao D, Yang L, Liu L, Yuan H, Qian S, Lv X, Han P, Wei Q. A comparison of nifedipine and tamsulosin as medical expulsive theraphy for the management of lower ureteral stones without ESWL. Sci Rep. 2014;4:5254. https:/doi.org/10.1038/srep05254.

8. Chaudhary D, Paudel S, Rana RM, Timsina S, Malla KP, Giri PM, Neupane BP Inhibition of calcium oxalate crystallization in vitro by methanolic leaf extract of Murraya koenigii (L.) Spreng. Int J Herb Med. 2018;6(2):13-5.

9. Colella J, Kochis E, Galli B, Munver R. Urolithiasis/nephrolithiasis: what's it all about? Urol Nurs. 2005;25(6):427-47.

10. Dellabella M, Milanese G, Muzzonigro G. Randomized trial of the efficacy of tamsulosin, nifedipine and phloroglucinol in medical expulsive therapy for distal ureteral calculi. J Urol. 2005;174(1):167-72. https://doi.org/10.1097/01 ju.0000161600.54732.86.

11. Fouada A, Yamina S, Nait MA, Mohammed B, Abdlekrim R. In vitro and in vivo antilithiatic effect of saponin rich fraction isolated from Herniaria hirsuta. J Bras Nefrol. 2006;28:199-203.
12. Garimella TS, Jolly Cl, Narayanan S. In vitro studies on antilithiatic activity of seeds of Dolichosbiflorus Linn and Rhizomes of Bergenia ligulata wall. Phytother Res. 2001;15(4):351-5.

13. Harborne JB. Phytochemical methods: a guide to modern techniques of plant analysis. 3rd ed. Heidelberg: Springer; 1998.

14. Hennequin C, Lalanne V, Daudon M, Lacour B, Drueke T. A new approach to studying inhibitors of calcium oxalate crystal growth. Urol. Res. 1993;21:101-8.

15. Hess B, Nakagawa Y, Coe FL. Inhibition of calcium oxalate monohydrate crystal aggregation by urine proteins. Am J Phys. 1989;257:F99-F106.

16. Ho LH, Noor Aziah AA, Bhat R. Mineral composition and pasting properties of banana pseudo-stem flour from Musaacuminata x balbisiana cv. Awak grown locally in Perak, Malaysia. Int Food Res J. 2012;19:1479.

17. Islam M, Islam M, Hooda M, Alam A, Chowdhury G, Shameem I. The comparison and efficacy of nifedipine and tamsulosin for the management of lower ureteric stones. Bangladesh J Urol. 2012;13(1):5-9.

18. Kalpana S, Nirmaladevi R, Shrinidhi-Rai R, Karthika P. Inhibition of calcium oxalate crystallization in vitro by extract of banana cultivar mothan. Int J Pharm Pharm Sci. 2013;5(4):649-53

19. Kandasamy S, Baggu C, Javagal MR, Lingamallu JR, Yenamandra V, Aradhya SM. Antioxidant properties of isolated compounds from banana rhizome. J Food Sci. 2014:79:H988-1001.

20. Karamakar D, Patki P. Evaluation of efficacy and safety of a herbal formulation cystone in the management of urolithiasis: meta-analysisof 50 clinical studies. Int J Altern Med. 2013;8(1):1-10.

21. Khan SR, Shevock PN, Hackett RL. Presence of lipids in urinary stones: results of preliminary studies. Calcif Tissue Int. 1988:42:91-6.

22. Kulkarni N, Kapse N, Pachori R, Sadar P. Studies on inhibition of calcium oxalate crystallisation by using plant extract and soil microflora. Eur J Pharm Med Res. 2017:4(8):329-34

23. Manish AP, Paras KP, Avinash KS. Inhibition of calcium oxalate crystallization by the fruit extracts of Piper nigrum L. Pharmacologyonline. 2011;2:1169-77.

24. Onyema CT, Ofor CE, Okudo VC, Ogbuagu AS. Phytochemical and antimicrobial analysis of banana pseudo stem (Musa acuminata). J Pharma Res Int. 2016:1-9.

25. Palaniyamma D, Jeyaraman R. Evaluation of Efficacy and Safety of a Herbal Formulation Cystone Forte in the Management of Urolithiasis. J Urol. Res. 2017:4(4):1093.

26. Panigrahi PN, Dey S, Sahoo M, Dan A. Antiurolithiatic and antioxidant efficacy of Musa paradisiacapseudo-stem on ethylene glycol-induced nephrolithiasis in rat. Indian J Pharm. 2017a;49(1):77-83.

27. Pawar AT, Vyawahare NS. Protective effect of ethyl acetate fraction of biophytum sensitivum extract against sodium oxalate-induced urolithiasis in rats. J Tradit Complement Med. 2017;7(4):476-86.

28. Pereira A, Maraschin M. Banana (Musaspp) from peel to pulp: ethnopharmacology, source of bioactive compounds and its relevance for human health. J Ethnopharmacol. 2015:160:149-63.

29. Phatak RS, Hendre AS. In-vitro Antiurolithiatic activity of Kalanchoe pinnato extract. Int J Pharmacognosy Phytochem Res. 2015;7(2):275-9.

30. Pinjarkar RV, Nazia DK, Zia HK, Mular SM. Study on in vitro antiurolithiatic activity of Bryophyllumpinnatumand Ocimumgratissimumleaves. Biosci Discov. 2017:8(2):290-4.

31. Porpiglia F, Ghignone G, Cristian F, Fontana D, Scarpa RM. Nifedipine versus tamsulosin for the management of lower ureteral stones. J Urol. 2004;172: 568-71.

32. R S, G J. Study of in vitro anti-urolithiatic effect of Ipomoea batatas ( $L$ ) leaves and tuberous roots. Asian J Pharm Clin Res. 2018;11(2):427-31.

33. Rajeswari P, Rajeswari G, Jabbrirulla SK, Vardhan IV. Evaluation of in vitro anti-urolithiasis activity of Convolvulus arvensis. Int J Pharm Pharm Sci. 2013: 5(3):599-601.

34. Ratkalkar VN, Kleinman JG. Mekanismes of stone formation. Clin Rev Bone Miner Metab. 2011:9(3-4):187-97.

35. Sablani SS, Shrestha AK, Bhandari BRA. New method of producing date powder granules: physicochemical characteristics of powder. J Food Eng. 2008;87:416-21

36. Saha S, Verma RJ. Inhibition of calcium oxalate crystallisation in vitro by an extract of Bergenia ciliata. Arab J Urol. 2012;11(2):187-92.

37. Sampath Kumar KP, Bhowmik D, Duraivel S, Umadevi M. Traditional and medicinal uses of banana. J Pharmacogn. Phytochem. 2012;1:53.

38. Shams KA, Abdel-Azim NS, Saleh IA, Hegazy MEF, ElMissiry MM, Hammouda FM. Review article green technology: economically and environmentally 
innovative methods for extraction of medicinal \& aromatic plants (MAP) in Egypt. J Chem Pharm Res. 2015;7(5):1050-74.

39. Sharma D, Dey YN, Sikarwar I, Sijoria R, Wanjari MM, Jadhav AD. In vitro study of aqueous leaf extract of Chenopodium album for inhibition of calcium oxalate and brushite crystallization. Egypt J Basic Appl Sci. 2016;3(2): 164-71.

40. Sharma I, Khan W, Parveen R, Alam MJ, Ahmad I, Ansari MHR, Ahmad S. Antiurolithiasis activity of bioactivity guided fraction of Bergenia ligulata against ethylene glycol induced renal calculi in rat. Biomed Res Int. 2017. https://doi.org/10.1155/2017/1969525.

41. Sivaraman D. Evaluation of anti- urolithiasis potential of Indian medicinal herbs Ficushispida, Morindatinctoria and Sapindusemarginatus by struvite crystal growth inhibition assay. Int J ChemTech Res. 2017;10(10):436-48.

42. Sujatha D, Singh K, Vohra M, Kumar KV, Sunitha S. Antilithiatic activity of phlorotannin rich extract of Sarghassum Wightii on calcium oxalate urolithiais - in vitro and in vivo evaluation. Int Braz J Urol. 2015;41(3):511-20.

43. Tan JS, Phapugrangkul P, Lee CK, Lai ZW, Bakar MHA, Murugan P. Banana frond juice as novel fermentation substrate for bioethanol production by Saccharomyces cerevisiae. Biocatal Agric Biotechnol. 2019;21:101293.

44. Vekilov PG. Nucleation. Cryst Growth Des. 2010;10(12):5007-19.

45. Verma P, Gauttam V, Kalia AN. Comparative pharmacognosy of pashanbhed. J Ayurveda Integr Med. 2014;5(2):104-8.

\section{Publisher's Note}

Springer Nature remains neutral with regard to jurisdictional claims in published maps and institutional affiliations.

Ready to submit your research? Choose BMC and benefit from:

- fast, convenient online submission

- thorough peer review by experienced researchers in your field

- rapid publication on acceptance

- support for research data, including large and complex data types

- gold Open Access which fosters wider collaboration and increased citations

- maximum visibility for your research: over $100 \mathrm{M}$ website views per year

At $\mathrm{BMC}$, research is always in progress.

Learn more biomedcentral.com/submissions 